\title{
Reinterpretation of metamorphic age of the Hengshan Complex, North China Craton
}

\author{
ZHANG YingHui ${ }^{1}$, WEI CunJing ${ }^{1 *}$, TIAN $\mathrm{Wei}^{1}{ }^{2}$ Z ZHOU XiWen ${ }^{2}$ \\ ${ }^{1}$ Key Laboratory of the Orogenic Belt and Crustal Evolution, Ministry of Education; School of Earth and Space Sciences, Peking University, \\ Beijing 100871, China; \\ ${ }^{2}$ Institute of Geology, Chinese Academy of Geological Sciences, Beijing 100037, China
}

Received March 25, 2013; accepted May 3, 2013; published online July 22, 2013

\begin{abstract}
Hengshan granulite facies terrane consists of tonalite-trondhjemite-granodiorite (TTG) gneisses and minor high-pressure mafic

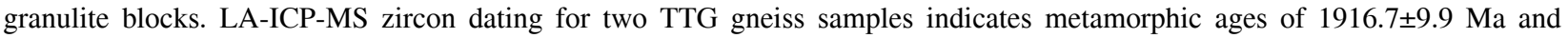
1850-1930 Ma, and magmatic protolith age of ca. $2.5 \mathrm{Ga}$, with similar HREE-rich patterns. Phase equilibria modelling in $\mathrm{ZrO}_{2^{-}}$ bearing system reveals that zircon abundance varies inversely with melt abundance in suprasolidus metamorphism, zircon growth occurs with melt crystallization during cooling, and thus, the newly grown zircon can only record the age of retrograde metamorphism. Consequently, we suggest that the Hengshan granulite facies terrane experienced slowly uplifting and cooling during 1.85$1.93 \mathrm{Ga}$ in an extensional setting under middle-crust, while the collision orogeny corresponding to peak stage of high-pressure granulite may have happened much earlier.
\end{abstract}

zircon U-Pb dating, $P-T$ pseudosection, Hengshan Complex, North China Craton

Citation: Zhang Y H, Wei C J, Tian W, et al. Reinterpretation of metamorphic age of the Hengshan Complex, North China Craton. Chin Sci Bull, 2013, 58: 4300-4307, doi: 10.1007/s11434-013-5993-x

There are two viewpoints about tectonic attributes and evolution of the North China Craton (NCC) in the Neoarchean-Paleoproterozoic. One view argues that the NCC was cratonized by amalgamation of micro-blocks and island arcs at ca. 2.5 Ga [1-5], experienced a series of intra-continent orogenic events of rifting-subduction-accretion-collision from an extensional regime $(2.3-2.0 \mathrm{Ga})$ to a compressional setting (2.01-1.97 Ga) during the Paleoproterozoic [4-6], and followed by high- and medium-pressure granulite facies metamorphism and uplifting during 1.95-1.82 Ga. However, it is still controversial whether the tectonic setting during 1.95-1.82 Ga was dominated by extension related to mantle upwelling [5] or by an orogenic environment of subduction and collision [4]. The other view suggests that the NCC experienced a continuous oceanic subduction since the Neoarchean, a collision between the Yinshan and Ordos Blocks

*Corresponding author (email: cjwei@pku.edu.cn) forming the Western Block at ca. $1.95 \mathrm{Ga}$, and a collision between the Western and Eastern blocks at 1.80-1.89 Ga forming the Trans-North China Orogen, marking the final amalgamation of the NCC [7-13]. The latter view is popularly supported [14-21]. At present, the metamorphic ages 1.80-1.89 Ga obtained from the Trans-North China Orogen are mostly interpreted as record of a subduction-collision process [12-15,18,20-25], but a few people suggest that they may represent an age of sustained extension [5]. Therefore, understanding meaning of the metamorphic ages 1.80$1.89 \mathrm{Ga}$ is crucial for elucidating the Paleoproterozoic evolution of the NCC. In this paper, we present LA-ICP-MS zircon $\mathrm{U}-\mathrm{Pb}$ and trace element data and $P-T$ pseudosection modelling results for tonalite-trondhjemite-granodiorite (TTG) gneisses from the Hengshan high-pressure granulite terrane, for elucidating the behaviours of zircon and melt under granulite facies and recognizing the geological significance of zircon ages. 


\section{Geological setting and sample descriptions}

The Hengshan high-grade gneiss terrane in the central TransNorth China Orogen is separated into the northern and southern Hengshan sub-terranes by Zhujiafang shear zone (Figure 1). The northern Hengshan sub-terrane is dominated by intensive migmatized TTG gneisses, with numerous high-pressure mafic granulite blocks and granitic intrusions, being granulite facies. SHRIMP zircon U-Pb dating suggests that protolith of the TTG gneisses was emplaced at 2.48-2.52 Ga, representing arc magmatism in the Neoarchean [14]. The TTG gneisses have a mineral assemblage of amphibolite facies and develop intense partial melting, producing numerous granitic leucosomes, veins and small intrusions. A part of these granitic rocks share similar ages of 1.85-1.87 Ga [23] to the granulite facies metamorphism, while others show older ages of 2.05-2.35 Ga and ca. $2.5 \mathrm{Ga}$ $[15,26]$. High-pressure mafic granulites occur as boudins or lens in TTG gneisses (Figure 2(a)), most of which develop amphibolite facies overprinting in the margins, with granulite facies assemblages preserved in the cores of blocks. Some mafic granulites are observed to have melt patches resulted from partial melting of host rocks [23]. Kröner et al. [23] obtained a metamorphic age of 1.85-1.88 Ga and a protolith (mafic dyke) emplacement age of ca. 1915 Ma for high-pressure mafic granulites using SHRIMP zircon U-Pb method.
The southern Hengshan sub-terrane consists of TTG gneisses, supracrustal sequence, weak-deformed mafic dykes and granitic rocks. The supracrustal sequence includes garnet amphibolite, plagiogneiss, mica schist and garnet orthoamphibolite, which are metamorphosed under amphibolite facies with a metamorphic zircon age of 1.90-1.91 Ga $[15,27,28]$. The weak-deformed mafic dykes are dated to have a protolith age of ca. $2.06 \mathrm{Ga}$ [29] and a metamorphic age of 1.85-1.87 Ga using SHRIMP zircon U-Pb method [23,29].

Two TTG gneiss samples in this study were collected at Small Stone Valley (Xiaoshiyu), northern Hengshan. Sample $\mathrm{H} 912$ is a quartz dioritic biotite- hornblende plagiogneiss consisting plagioclase $50 \mathrm{vol} \%$, quartz 10\%, hornblende $25 \%$, biotite $8 \%$, K-feldspar $4 \%$, and $3 \%$ accessory minerals involving apatite, zircon, sphene (Figure 2(c)). Sample WT1131 is a trondhjemitic biotite plagiogneiss consisting of plagioclase $47 \%$, quartz $25 \%$, K-feldspar $10 \%$, biotite $10 \%$, hornblende $5 \%$, and accessory minerals $3 \%$.

\section{Zircon $\mathrm{U}-\mathrm{Pb}$ geochronology and trace element analysis}

Zircon Cathodoluminescence (CL) images were obtained using a scanning electron microscope at the SEM Laboratory of Peking University. The U-Pb ages and trace element

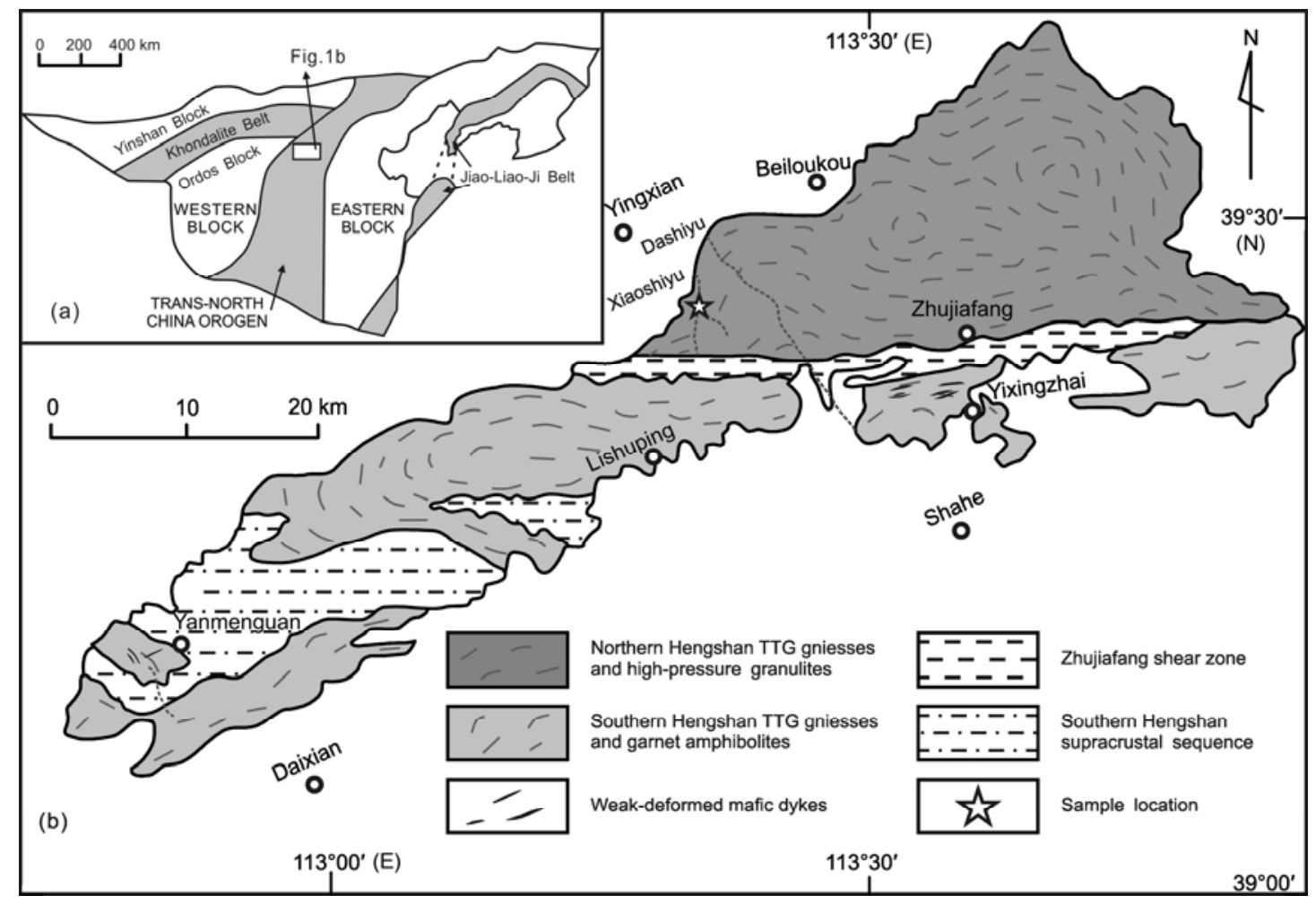

Figure 1 Tectonic framework of the North China Craton and location of the study area ((a) after Zhao et al. [11]) and simplified geological map of the Hengshan high-grade gneiss terrane and the sample location ((b) after Kröner et al. [23]). 


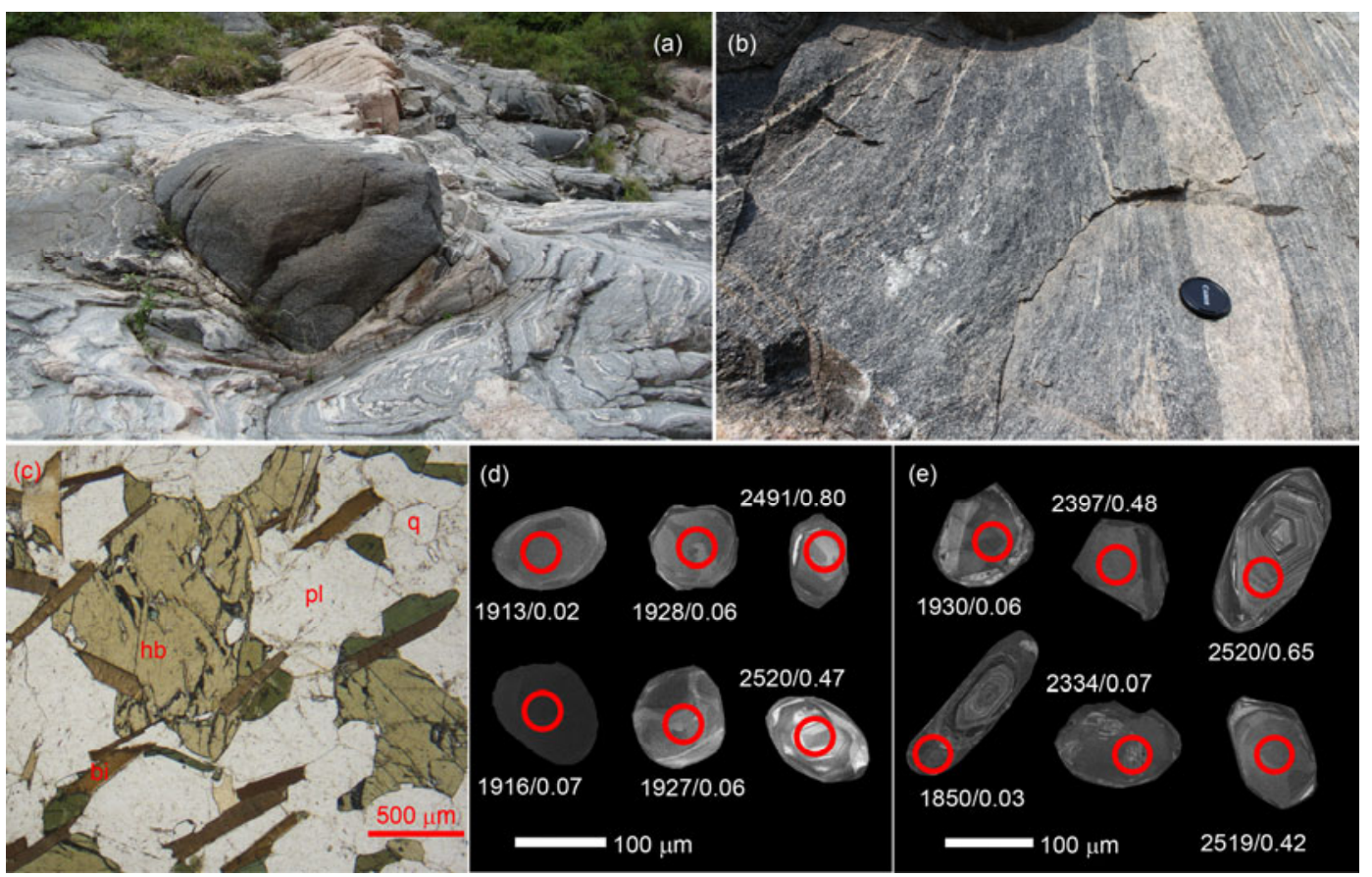

Figure 2 Field occurrence of the Hengshan migmatitic TTG gneisses and high-pressure mafic granulite blocks (a), (b), microphotograph showing petrographic relations in sample H912 (c), and cathodoluminescence images of analysed zircon grains from H912 (d) and WT1131(e). hb, hornblende; pl, plagioclase; bi, biotite; q, quartz. Locations of laser analysis are depicted as red circles, and numbers refer to ${ }^{207} \mathrm{~Pb} /{ }^{206} \mathrm{~Pb}$ ages $(\mathrm{Ma}) / \mathrm{Th} / \mathrm{U}$ ratios.

analyses for zircon were undertaken by an Agilent 7500ce ICP-MS equipped with a $193 \mathrm{~nm}$ excimer laser ablation system (COMPexPro 102) at the Key Laboratory of Orogenic Belts and Crustal Evolution, Peking University, for sample H912, and by an Agilent 7500a ICP-MS connected to an $193 \mathrm{~nm}$ excimer laser ablation system of American New Wave UP 193 SS at the Geological Lab Center, China University of Geosciences Beijing, for sample WT1131. The standard silicate glass NIST SRM 610 was used to calculate $\mathrm{U}$, Th and $\mathrm{Pb}$ concentrations. The ${ }^{207} \mathrm{~Pb} /{ }^{206} \mathrm{~Pb}$ and ${ }^{206} \mathrm{~Pb} /{ }^{238} \mathrm{U}$ ratios were calculated using the GLITTER 4.4 program, and then corrected using the zircon PLE [30] (for H912) and 91500 [31] (for WT1131) as external standard. Errors on individual analysis by LA-ICP-MS and weighted mean ages are quoted at the $1 \sigma$ and $2 \sigma$ confidence level, respectively. Common $\mathrm{Pb}$ was corrected according to the method described by Andersen [32]. Data were processed using the software ISOPLOT [33] v3.75.

Zircon in sample H912 is mostly clear and rounded, with grain size of 100-150 $\mu \mathrm{m}$ and length/width ratios of 1-1.5. Most grains are unzoned, weakly zoned or show sector zoning in CL images (Figure 2(d)), characteristic of metamorphic growth. A few grains are short-prismatic with length/ width ratios of $\sim 2$ and show oscillatory zoning of magmatic origin. Several grains have inherited magmatic cores and metamorphic overgrowths. Nineteen zircon grains were analyzed. Four grains of magmatic origin contain $\mathrm{Th}=21.3-89.4$ ppm, $\mathrm{U}=45.2-87.9 \mathrm{ppm}$ and $\mathrm{Th} / \mathrm{U}=0.47-1.02$ and yield concordant ages with a weighted mean ${ }^{207} \mathrm{~Pb} /{ }^{206} \mathrm{~Pb}$ age of
$2501 \pm 19 \mathrm{Ma}$ and $\mathrm{MSWD}=0.55$. Fifteen grains of metamorphic origin contain $\mathrm{Th}=2.82-16.6 \mathrm{ppm}, \mathrm{U}=78.8-384 \mathrm{ppm}$ and $\mathrm{Th} / \mathrm{U}=0.01-0.07$ (one grain is 0.13 ) and yield nearly concordant ages with a weighted mean ${ }^{207} \mathrm{~Pb} /{ }^{206} \mathrm{~Pb}$ age of 1916.7 $\pm 9.9 \mathrm{Ma}$ and MSWD=0.73. All these zircons are enriched in HREE with positive Ce anomalies. The magmatic zircons have relatively high REE contents with negative Eu anomalies, but the metamorphic zircons have relatively low REE contents without obvious Eu anomalies and are relatively depleted in MREE (Figure 3(c)).

Zircon in sample WT1131 is colorless to pale yellow, short-prismatic or rounded and 50-200 $\mu \mathrm{m}$ across with length/width ratios of $1-3$. The analyzed 37 grains show $\mathrm{Th}=10.2-949 \mathrm{ppm}$ and $\mathrm{U}=31.9-3399 \mathrm{ppm}$, and can be separated into three groups in Figure 3(b). Group one involving 28 grains with $\mathrm{Th} / \mathrm{U}=0.05-0.97$, mostly shows distinct oscillatory zoning of magmatic origin (Figure 2(e)), but a few grains have weak zoning and low-luminescent. They are mostly concordant around $2500 \mathrm{Ma}$ in Figure 3(b), whereas 4 grains are variably discordant due to Pb-loss. All of them are fitted to a discordia with an upper intercept age of $2500 \pm 15 \mathrm{Ma}$ and MSWD=0.59. Group two involving five grains which show unclear inner structure and dark-luminescent with $\mathrm{Th} / \mathrm{U}=0.07-0.48$, is fitted to a discordia with an upper intercept age of $2369 \pm 34 \mathrm{Ma}$ and MSWD $=0.72$, where two grains are virtually concordant. Four grains in group three involve rounded weak zoning grains or darkluminescent rims of metamorphic origin, and have low $\mathrm{Th} / \mathrm{U}$ ratios $0.02-0.06$. They yield four near-concordant 

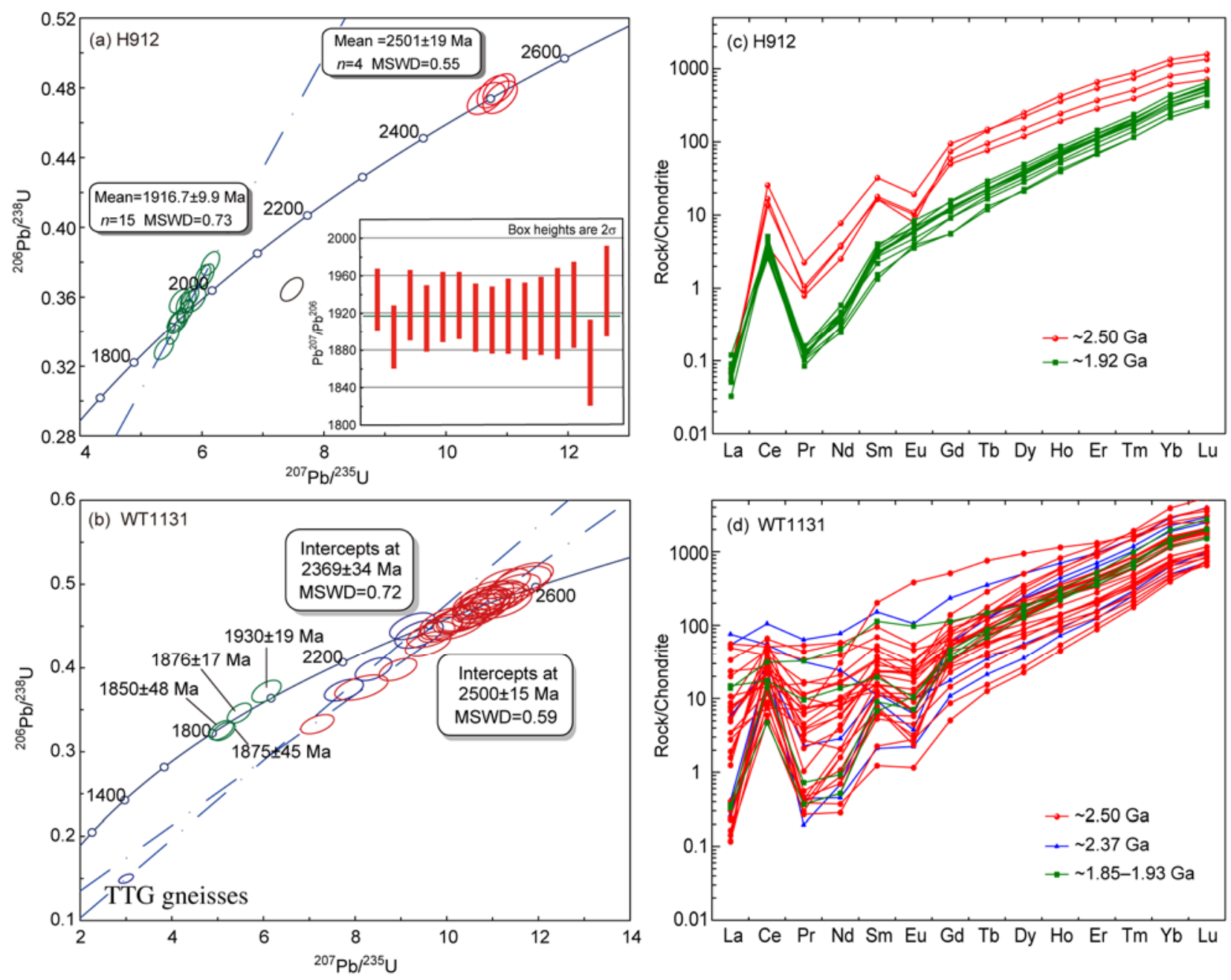

Figure 3 Concordia diagrams showing LA-ICP-MS U-Pb analyses and chondrite normalised REE patterns of zircon from the Hengshan TTG gneiss for sample H912 ((a), (c)) and WT1131((b), (d)). The REE data of chondrite are cited from Boynton [34].

${ }^{207} \mathrm{~Pb} /{ }^{206} \mathrm{~Pb}$ ages of $1850 \pm 48 \mathrm{Ma}, 1875 \pm 45 \mathrm{Ma}, 1876 \pm 17 \mathrm{Ma}$, and $1930 \pm 19 \mathrm{Ma}$. The three groups of zircon show similar REE patterns enriched in HREE with negative Eu anomalies and different positive $\mathrm{Ce}$ anomalies, but with variable LREE contents (Figure 3(d)).

\section{Phase equilibria modelling}

For modelling the behavior of zircon dissolution and growth during high-grade metamorphism, we calculated a $P-T$ pseudosection for sample $\mathrm{H} 912$ (Figure 4) in a $\mathrm{ZrO}_{2}$-bearing system NCKFMASHTOZr $\left(\mathrm{Na}_{2} \mathrm{O}-\mathrm{CaO}-\mathrm{K}_{2} \mathrm{O}-\mathrm{FeO}-\mathrm{MgO}-\right.$ $\mathrm{Al}_{2} \mathrm{O}_{3}-\mathrm{SiO}_{2}-\mathrm{H}_{2} \mathrm{O}-\mathrm{TiO}_{2}-\mathrm{O}-\mathrm{ZrO}_{2}$ ), using the THERMOCALC program 3.33i [35]. Activity-composition (a-x) models of phases involved are after Kelsey \& Powell [36], Diener et al. [37] and Green et al. [38]. $\mathrm{Zr}$ is assumed to be present in zircon, silicate melt, rutile and garnet, and is neglected in ilmenite, orthopryroxene, biotite and hornblende [39] due to lack of appropriate a-x models. A preliminary mass balance calculation reveals that such a consideration of $\mathrm{a}-\mathrm{x}$ models is appropriate for modelling the variation between melt and zircon. The bulk composition for $\mathrm{H} 912$ obtained by XRF method is $\mathrm{SiO}_{2}=61.01$ (mol.\%), $\mathrm{Al}_{2} \mathrm{O}_{3}=10.01, \mathrm{CaO}=7.18$, $\mathrm{MgO}=7.13, \mathrm{FeO}=5.19, \mathrm{~K}_{2} \mathrm{O}=0.79, \mathrm{Na}_{2} \mathrm{O}=3.48, \mathrm{TiO}_{2}=0.49$, $\mathrm{H}_{2} \mathrm{O}=4.73$ calculated from loss on ignition, $\mathrm{ZrO}_{2}=0.00352$ (52 ppm) produced by trace elements analysis, and $\mathrm{O}$ $\left(\mathrm{Fe}_{2} \mathrm{O}_{3}\right)=0.94$ calculated from the average value of tonalitic gneiss in Hengshan [40].

In Figure 4, the water-saturated solidus is present in $660-750^{\circ} \mathrm{C}$ and shows negative slope below $1.1 \mathrm{GPa}$ but positive slope at higher pressure. Garnet appears in assemblages above $1.0 \mathrm{GPa}$ and zircon disappears at $820-880^{\circ} \mathrm{C}$. Contours of zircon and melt abundance show steep slopes in most suprasolidus assemblages, being temperature-dependent. Zircon abundance decreases and melt increases with increasing temperature.

Considering that the Hengshan TTG gneisses and highpressure mafic granulites may have undergone the same metamorphic evolution [23,41], a $P-T$ path obtained from 


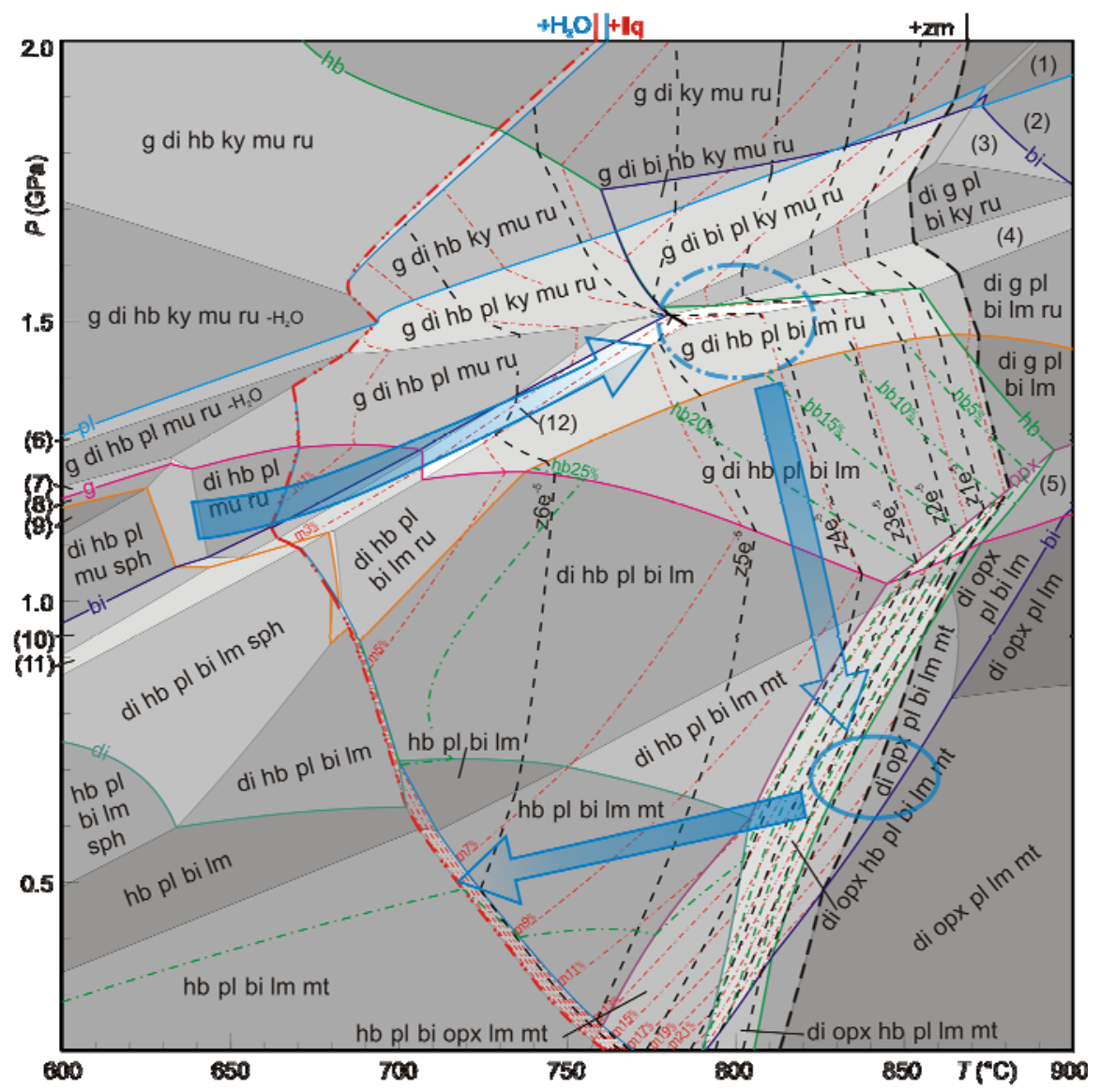

Figure $4 P-T$ pseudosection in the NCKFMASHTOZr+q system for sample H912. Black solid line: univariant reaction; 0-50\% gray scale shaded: bivariant-septivariant fields; color solid lines: stability limits of the main phases concerned; red dotted lines: melt mode isopleths; black dash lines: zircon mode isopleths; green dotted lines: hornblende mode isopleths. All the suprasolidus assemblages include melt and most subsolidus assemblages include water fluid. di, diopside; opx, orthopyroxene; g, garnet; mu, muscovite; ky, kyanite; sph, sphene; ru, rutile; lm, ilmenite; mt, magnetite; zrn, zircon; liq, silicate melt; other abbreviations are the same as in Figure 2. Mineral assemblages: (1) di g ky ksp ru liq q, (2) di g pl ky ksp ru liq q, (3) di g pl ksp bi ky ru liq q, (4) di g pl bi lm ky ru liq q, (5) di g opx pl bi lm liq q, (6) di g hb ky pl mu ru zrn q, (7) di g hb pl mu ru zrn sph q, (8) di hb pl bi mu ru zrn sph q, (9) di hb pl mu zrn sph q, (10) di hb pl bi mu zrn sph q $\mathrm{H}_{2} \mathrm{O}$, (11) di hb pl bi mu lm zrn sph q $\mathrm{H}_{2} \mathrm{O}$, (12) g di hb pl bi mu lm ru zrn q liq.

mafic granulites is displayed in Figure 4. During the suprasolidus prograde metamorphism, melt abundance increases together with zircon decreasing. At the peak stage of highpressure granulite facies, the probable assemblage in the rock is garnet+clinopyroxene+hornblende+plagioclase+biotite+ rutile+quartz+zircon \pm kynite \pm muscovite \pm ilmenite. During the subsequent decompression or uplifting, zircon and melt abundances slighly vary in the garnet-bearing assemblages. However, after garnet disappears and especially after orthopyroxene appears, melt abundance increases rapidly and zircon tends to be consumed as a consequence of hornblende and biotite dyhydration melting reaction, which is probably hornblende+biotite+quartz+zircon=clinopyroxene+orthopyroxene+melt. Up to the peak temperature (two-pyroxene granulite facies) stage, the assemblage is modelled to be clinopyroxene+orthopyroxene+plagioclase+quartz+Ti-Fe oxide \pm biotite \pm hornblende \pm zircon. Zircon will completely dissolve into melt when temperature exceeds $840^{\circ} \mathrm{C}$. During cooling, the reverse reaction of the above-mentioned melting reaction occurs firstly, resulting in crystallization of a mass of melt and zircon growth, then orthopyroxene and clinopyroxene disappear sequentially at $\sim 800^{\circ} \mathrm{C}$, and finally the remaining melt crystallizes in the melt-fluid coexisting narrow area close to the solidus at $\sim 720^{\circ} \mathrm{C}$, releasing fluids coupled with further zircon growth.

\section{Discussion and conclusion}

Phase equilibria modelling in the $\mathrm{ZrO}_{2}$-bearing system for a TTG gneiss with composition of sample $\mathrm{H} 912$ shows that during the suprasolidus $\left(>660^{\circ} \mathrm{C}\right)$ metamorphic process from the prograde, to the peak pressure and the subsequent decomposition with heating to the peak temperature stage, melt abundance keeps increasing coupling with zircon dissolving, and thus, there would be no zircon growth and age records. Only during cooling, zircon could grow and record age with melt crystallization. Hence in melt-bearing high-grade metamorphic rocks, newly grown zircon should record the age of melt crystallization or the resulting fluid activity. For the 
cooling path in Figure 4, zircon can grow from $>800^{\circ} \mathrm{C}$ to $<720^{\circ} \mathrm{C}$, yielding different ages. We propose that the metamorphic age 1916.7 \pm 9.9 Ma obtained for sample H912 may represent the early cooling stage for there would be a large amount of melt crystallization and zircon growth in the early cooling stage as shown in Figure 4. Moreover, this inference can also be supported from zircon REE patterns. As abundant hornblende would be formed with the melt crystallization and zircon growth in the early cooling stage, and hornblende contains considerably high REE content especially with high MREE and has negative Eu anomaly [42-44] if it is in equilibrium with Ca-rich plagioclase at low pressure, the simultaneously grown zircon may have lower REE content without Eu anomaly and more strongly fractionated MREE to HREE patten. Sample WT1131 contains a small amount of hornblende, which may have trivial affects on the Eu anomalies in zircon. This may be the reason why some zircon grains with ages of 1.85-1.93 $\mathrm{Ga}$ show distinct negative $\mathrm{Eu}$ anomalies (Figure 3(d)). In addition, zircon grains of metamorphic origin in both samples show HREE-enriched REE patterns without the signature of garnet presence, revealing that zircon may have mosltly grown after garnet decomposition.

Preliminary phase equilibria modelling for rocks with different bulk compositions including mafic granulites shows the similar melt-zircon behaviors to those in Figure 4. Hence it could be inferred that zircon in these rocks can only record ages of cooling. However, as various ways and degrees of melt extraction, segregation and crystallization may occur in rocks of different bulk compositions and structural positions, zircon from a high-grade terrane may record a series of ages, most of which, however, should be close to the age when the cooling path crosses the solidus. For example, if the age 1.85-1.87 Ga [23] for granitic veins which cut mafic granulites in the northern Hengshan sub-terrane is considered to represent melt crystallization, most highpressure granulites should yield the similar ages which are actually 1.85-1.89 Ga [23], suggesting they may not correspond to the peak stage of metamorphism. Four zircon grains in sample WT1131 record a long cooling process from 1.93 Ga to $1.85 \mathrm{Ga}$, indicating the northern Hengshan sub-terrane keeping suprasolidus condition in middle crust over $80 \mathrm{Ma}$.

Kröner et al. [23] interpreted two zircon ages of ca. 1915 Ma to be the emplacement age of protolith of the Hengshan high-pressure granulites. This was argued by Peng et al. [29] from zircon morphology. Zircon in Kröner et al. [23] displays typical magmatic oscillatory zoning but has low Th/U ratios with an average of 0.04 , very similar to zircon crystallized from anatectic melt $[45,46]$. Moreover, there are also zircon grains which yield ages of ca. 2.1 Ga in Kröner et al. [23], corresponding to the age of weak-deformed mafic dykes in the southern Hengshan [29]. Therefore we are inclined to regard the age ca. $1915 \mathrm{Ma}$ as a metamorphic record of cooling of granulites.

The amphibolite facies rocks in the southern Hengshan and the Jingangku Formation of the Wutai Group should be a shallower crust equivalent of the northern Hengshan granulite sub-terrane in a same orogenic event $[10,47]$. As mentioned above, metamorphic zircons from the southern Hengshan supracrustal rocks and mafic dykes yield ages of 1.90$1.91 \mathrm{Ga}$ and ca. $1.85 \mathrm{Ga}$. The similar two groups of age are also reported in the Wutai and Lüliang Groups: for example, a Sm-Nd whole rock and mineral isochron age of ca. 1.91 Ga for garnet amphibolite [47], two groups of monazite Th-U-Pb age of 1.92-1.93 Ga and 1.82-1.85 Ga [18,47] for metapelites in the Wutai Group, and also two groups of monazite age of 1.92-1.94 Ga from grain cores and 1.85$1.88 \mathrm{Ga}$ or younger from grain rims for metapelites in the Lüliang Group [18,48]. So far, the younger age group is mostly interpreted to represent the peak metamorphic stages of amphibolite and granulite facies, coeval with the collision between the Eastern and Western Blocks [12,14,15, $18,23,48,49]$. However, it contradicts the thermal modelling results of England and Thompson [50] that different grades of rock with one $P-T$ array share a same age at peak stages. As to the older age group, its geological significance is still ambiguous [48]. Combined with the results in this paper, we can not rule out a possibility that these amphibolite facies rocks may have experienced the similar slow uplifting and cooling to that in the northern Hengshan granulite sub-terrane, and the collision event before this uplifting could be much earlier than the reported ages. The Paleoproterozoic orogeny in the Hengshan-Wutai area, especially in the granulite sub-terrane may have lasted $>100$ Ma involving crust collision and thickening, heating and uplifting, and cooling.

Such a long and slow uplifting and cooling orogeny can also be supported by recent numerical modelling results. For example, modelling of the Grenville Orogen by Jamieson and Beaumont [51] using model GO-ST87 suggests that the hot orogenic core zone may undergo protracted burial and heating and accompanying ductile flow at amphibolite and granulite facies conditions, which will last over $100 \mathrm{Ma}$. In this case, the age of peak metamorphism may be very difficult to determine because it is unlikely to correspond to any particular thermal or tectonic 'event', but evidence for the onset of exhumation and associated cooling may be recorded by medium-temperature chronometers.

We sincerely thank Su Li at the Geological Lab Center, China University of Geosciences Beijing and Ma Fang at Peking University for their help during the LA-ICP-MS zircon U-Pb dating, and Zhang Shuang and Qian Jiahui for their involvement in field and experimental work and helpful discussions. The two reviewers are much appreciated for their critical comments and valuable suggestions of the manuscript. This work was supported by the National Natural Science Foundation of China (41172055 and 41121062) and the China Survey of Geology (1212011121062).

1 Wu J S, Geng Y S, Shen Q H, et al. Archaean Geology Characteristics and Tectonic Evolution of China-Korea Paleo-continent (in Chinese). Beijing: Geological Publishing House, 1998. 1-212 
2 Zhai M G, Bian A G, Zhao T P. The amalgamation of the supercontinent of North China Craton at the end of Neo-Archaean and its breakup during late Palaeoproterozoic and Meso-Proterozoic. Sci China Ser D, 2000, 43: 219-232

3 Zhai M G, Guo J H, Liu W J. Neoarchean to Paleoproterozoic continental evolution and tectonic history of the North China Craton: A review. J Asian Earth Sci, 2005, 24: 547-561

4 Zhai M G, Santosh M. The early Precambrian odyssey of the North China Craton: A synoptic overview. Gondwana Res, 2011, 20: 6-25

5 Zhai M G. Cratonization and the Ancient North China Continent: A summary and review. Sci China Earth Sci, 2011, 8: 1110-1120

6 Zhai M G, Liu W J. Palaeoproterozoic tectonic history of the North China craton: A review. Precambrian Res, 2003, 122: 183-199

7 Zhao G C, Wilde S A, Cawood P A, et al. Thermal evolution of Archean basement rocks from the eastern part of the North China carton and its bearing on tectonic setting. Int Geol Rev, 1998, 40: 706-721

8 Zhao G C, Cawood P A, Lu L Z. Petrology and P-T history of the Wutai amphibolites: implications for tectonic evolution of the Wutai Complex, China. Precambrian Res, 1999, 93: 181-199

9 Zhao G C, Wilde S A, Cawood P A, et al. Tectonothermal history of the basement rocks in the western zone of the North China Craton and its tectonic implications. Tectonophysics, 1999, 310: 37-53

10 Zhao G C, Cawood P A, Wilde S A, et al. Metamorphism of basement rocks in the Central Zone of the North China Craton: Implications for Paleoproterozoic tectonic evolution. Precambrian Res, 2000, 103: 55-88

11 Zhao G C, Sun M, Wilde S A, et al. Late Archean to Paleoproterozoic evolution of the North China Craton: Key issues revisited. Precambrian Res, 2005, 136: 177-202

12 Zhao G C, Wilde S A, Sun M, et al. SHRIMP U-Pb zircon ages of granitoid rocks in the Lüliang Complex: Implications for the accretion and evolution of the Trans-North China Orogen. Precambrian Res, 2008, 160: 213-226

13 Zhao G C, Wilde S A, Guo J H, et al. Single zircon grains record two Paleoproterozoic collisional events in the North China Craton. Precambrian Res, 2010, 177: 266-276

14 Kröner A, Wilde S A, Li J H, et al. Age and evolution of a late Archean to Paleoproterozoic upper to lower crustal section in the $\mathrm{Wu}$ taishan/Hengshan/Fuping terrain of northern China. J Asian Earth Sci, 2005, 24: 577-595

15 Kröner A, Wilde S A, O'Brien P J, et al. Field relationships, geochemistry, zircon ages and evolution of a late Archaean to Palaeoproterozoic lower crustal section in the Hengshan Terrain of northern China. Acta Geol Sin-Engl, 2005, 79: 605-632

16 Wilde S A, Cawood P A, Wang K Y, et al. Granitoid evolution in the Late Archean Wutai Complex, North China Craton. J Asian Earth Sci, 2005, 24: 597-613

17 Liu S W, Pan Y M, Xie Q L, et al. Archean geodynamics in the Central Zone, North China Craton: Constraints from geochemistry of two contrasting series of granitoids in the Fuping and Wutai complexes. Precambrian Res, 2004, 130: 229-249

18 Liu S W, Zhao G C, Wilde S A, et al. Th-U-Pb monazite geochronology of the Lüliang and Wutai Complexes: Constraints on the tectonothermal evolution of the Trans-North China Orogen. Precambrian Res, 2006, 148: 205-224

19 Liu S W, Zhang J, Li Q G, et al. Geochemistry and U-Pb zircon ages of metamorphic volcanic rocks of the Paleoproterozoic Lüliang Complex and constraints on the evolution of the Trans-North China Orogen, North China Craton. Precambrian Res, 2012, 222-223: 173190

20 Wan Y S, Song B, Liu D Y, et al. SHRIMP U-Pb zircon geochronology of Palaeoproterozoic metasedimentary rocks in the North China Craton: Evidence for a major Late Palaeoproterozoic tectonothermal event. Precambrian Res, 2006, 149: 249-271

21 Wan Y S, Wilde S A, Liu D Y, et al. Further evidence for $1.85 \mathrm{Ga}$ metamorphism in the Central Zone of the North China Craton: SHRIMP U-Pb dating of zircon from metamorphic rocks in the Lushan area, Henan Province. Gondwana Res, 2006, 9: 189-197

22 Guo J H, Sun M, Chen F K, et al. Sm-Nd and SHRIMP U-Pb zircon geochronology of high-pressure granulites in the Sanggan area, North China Craton: Timing of Paleoproterozoic continental collision. J Metamorph Geol, 2005, 24: 629-642

23 Kröner A, Wilde S A, Zhao G C, et al. Zircon geochronology and metamorphic evolution of mafic dykes in the Hengshan Complex of northern China: Evidence for late Palaeoproterozoic extension and subsequent high-pressure metamorphism in the North China Craton. Precambrian Res, 2006, 146: 45-67

24 Zhao G C, Wilde S A, Cawood P A, et al. SHRIMP U-Pb zircon ages of the Fuping Complex: Implications for late Archean to Paleoproterozoic accretion and assembly of the North China Craton. Am J Sci, 2002, 302: 191-226

25 Zhao G C, Wilde S A, Sun M, et al. SHRIMP U-Pb zircon geochronology of the Huai'an Complex: Constraints on Late Archean to Paleoproterozoic magmatic and metamorphic events in the TransNorth China Orogen. Am J Sci, 2008, 308: 270-303

26 Zhao R F, Guo J H, Peng P, et al. 2.1Ga crustal remelting event in Hengshan Complex: Evidence from zircon $\mathrm{U}-\mathrm{Pb}$ dating and $\mathrm{Hf}-\mathrm{Nd}$ isotopic study on potassic granites (in Chinese). Acta Petrol Sin, 2011, 27: $1607-1623$

27 Wang K Y, Hao J, Wilde S A, et al. Reconsideration of some key geological problems of late Archean-early Proterozoic in the WutaishanHengshan area: Constraints from SHRIMP U-Pb zircon data (in Chinese). Sci Geol Sin, 2000, 35: 175-184

28 Pang E C, Xu Y J, Shi G H, et al. Geochemistry and chronology of Hongtang ore-bearing rocks in the Daixian rutile deposit, Shanxi Province (in Chinese). Acta Petrologica Et Mineralogica, 2010, 29: 497-506

29 Peng P, Guo J, Zhai M, et al. Genesis of the Hengling magmatic belt in the North China Craton: Implications for Paleoproterozoic tectonics. Lithos, 2012, 148: 27-44

30 Sláma J, Kösler J, Condon D J, et al. Plešovice zircon-A new natural reference material for $\mathrm{U}-\mathrm{Pb}$ and $\mathrm{Hf}$ isotopic microanalysis. Chem Geol, 2008, 249: 1-35

31 Wiedenbeck M, Allé P, Corfu F, et al. Three Natural Zircon Standards for U-Th-Pb, Lu-Hf, Trace Element and REE Analyses. Geostand Newsl, 1995, 19: 1-23

32 Andersen T. Correction of common lead in $\mathrm{U}-\mathrm{Pb}$ analyses that do not report ${ }^{204} \mathrm{~Pb}$. Chem Geol, 2002, 192: 59-79

33 Ludwig K R. Isoplot/Ex Version 3.00: A geological toolkit for Microsoft Excel. Berkeley Geochronology Center Spec Publ 4, 2003 : $1-70$

34 Boynton W V. Cosmochemistry of the rare earth elements: Meteoric studies. In: Henderson P, ed. Rare Earth Element Geochemistry. Amsterdam: Elsevier, 1984. 63-114

35 Powell R, Holland T, Worley B. Calculating phase diagrams involving solid solutions via non-linear equations, with examples using THERMOCALC. J Metamorph Geol, 1998, 16: 577-588

36 Kelsey D E, Powell R. Progress in linking accessory mineral growth and breakdown to major mineral evolution in metamorphic rocks: A thermodynamic approach in the $\mathrm{Na}_{2} \mathrm{O}-\mathrm{CaO}-\mathrm{K}_{2} \mathrm{O}-\mathrm{FeO}-\mathrm{MgO}-\mathrm{Al}_{2} \mathrm{O}_{3}-\mathrm{SiO}_{2}$ $\mathrm{H}_{2} \mathrm{O}-\mathrm{TiO}_{2}-\mathrm{ZrO}_{2}$ system. J Metamorph Geol, 2011, 29: 151-166

37 Diener J F A, Powell R, White R W, et al. A new thermodynamic model for clino- and orthoamphiboles in the system $\mathrm{Na}_{2} \mathrm{O}-\mathrm{CaO}-\mathrm{FeO}-$ $\mathrm{MgO}-\mathrm{Al}_{2} \mathrm{O}_{3}-\mathrm{SiO}_{2}-\mathrm{H}_{2} \mathrm{O}-\mathrm{O}$. J Metamorph Geol, 2007, 25: 631-656

38 Green E, Holland T, Powell R. An order-disorder model for omphacitic pyroxenes in the system jadeite-diopside-hedenbergite-acmite, with applications to eclogitic rocks. Am Mineral, 2007, 92: 1181-1189

39 Bea F, Montero P, Ortega M. A LA-ICP-MS evaluation of Zr reservoirs in common crustal rocks: Implications for $\mathrm{Zr}$ and $\mathrm{Hf}$ geochemistry, and zircon-forming processes. Can Mineral, 2006, 44: 693-714

40 Li J H, Qian X L. The Early Precambrian Crustal Evolution of Hengshan Metamorphic Terrain, North China Craton (in Chinese). Taiyuan: Shanxi Science and Technology Press, 1994. 1-116

41 Zhao G, Cawood P A, Wilde S A, et al. High-Pressure Granulites (Retrograded Eclogites) from the Hengshan Complex, North China Craton: Petrology and Tectonic Implications. J Petrol, 2001, 42: 11411170

42 Nehring F, Foley S F, Holtta P. Trace element partitioning in the 
granulite facies. Contrib Mineral Petr, 2010, 159: 493-519

43 Spandler C, Hermann J, Arculus R, et al. Redistribution of trace elements during prograde metamorphism from lawsonite blueschist to eclogite facies; implications for deep subduction-zone processes. Contrib Mineral Petr, 2003, 146: 205-222

44 Hanson G N. The application of trace elements to the petrogenesis of igneous rocks of granitic composition. Earth Planet Sc Lett, 1978, 38: 26-43

45 Rubatto D. Zircon trace element geochemistry: Partitioning with garnet and the link between $\mathrm{U}-\mathrm{Pb}$ ages and metamorphism. Chem Geol, 2002, 184: 123-138

46 Wu Y B, Zheng Y F. Genesis of zircon and its constraints on interpretation of U-Pb age. Chin Sci Bull, 2004, 49: 1554-1569

47 Liu S W, Shu G M, Pan Y M, et al. Electron-Microprobe Dating of Monazite and Metamorphic Age of Wutai Group, Wutai Mountains (in Chinese). J China Univ Geosci, 2004, 10: 356-363

48 Trap P, Faure M, Lin W, et al. The Lüliang Massif: A key area for the understanding of the Palaeoproterozoic Trans-North China Belt, North China Craton. In: Reddy S M, Mazumder R, Evans D A D, et al., eds. Palaeoproterozoic Supercontinents and Global Evolution. Geol Soc London Spec Publ, 2009. 99-125

49 Trap P, Faure M, Lin W, et al. Paleoproterozoic tectonic evolution of the Trans-North China Orogen: Toward a comprehensive model. Precambrian Res, 2012, 222-223: 191-211

50 England P C, Thompson A B. Pressure-Temperature-Time Paths of Regional Metamorphism I. Heat Transfer during the Evolution of Regions of Thickened Continental Crust. J Petrol, 1984, 25: 894-928

51 Jamieson R A, Beaumont C. Coeval thrusting and extension during lower crustal ductile flow-Implications for exhumation of highgrade metamorphic rocks. J Metamorph Geol, 2011, 29: 33-51

Open Access This article is distributed under the terms of the Creative Commons Attribution License which permits any use, distribution, and reproduction in any medium, provided the original author(s) and source are credited. 